\title{
Contract theory and Theories of Contract Régulation
}

In: Revue d'économie industrielle. Vol. 92. 2e et 3eme trimestres 2000. pp. 101-110.

\begin{abstract}
This Essay considers the substantive and institutional aspects of an economic theory of contract regulation. It lists the various functions that analysts have assigned to contract regulation and briefly discusses the substantive wisdom and institutional feasibility of performing those functions. The essay tentatively concludes that the state should enforce contracts, supply vocabularies that are useful in writing contracts and supply default modes of economic organization, such as a corporate or bankruptcy code. Other possible state functions, such as supplying efficient default rules for use in contracts, may be beyond the ability of government to perform well.

\section{Résumé}

Cet essai examine ce que devrait être une théorie économique de la réglementation des contrats d'un point de vue institutionnel ou substantiel. II énumère les différentes fonctions que les analystes ont assignées à la réglementation des contrats et discute brièvement l'exercice de ces fonctions sous l'angle de leur faisabilité institutionnelle et de la prudence substantielle. Cet essai conclut, non sans hésitation, que l'État devrait assurer les fonctions suivantes : faire respecter les contrats, produire les terminologies qui sont utiles à la rédaction des contrats, produire les règles de défaillance de l'activité économique comme celles du droit des faillites et du droit des sociétés. D'autres fonctions possibles pour l'État, comme la production de règles efficaces de défaillance à utiliser dans la rédaction des contrats, nous semblent bien au-delà des compétences prouvées des gouvernements.
\end{abstract}

Citer ce document / Cite this document :

Schwartz Alan. Contract theory and Theories of Contract Régulation. In: Revue d'économie industrielle. Vol. 92. 2e et 3eme trimestres 2000. pp. 101-110.

doi : $10.3406 /$ rei.2000.1040

http://www.persee.fr/web/revues/home/prescript/article/rei_0154-3229_2000_num_92_1_1040 


\section{CONTRACT THEORY AND THEORIES OF CONTRACT REGULATION}

Mots-clés : Théorie des contrats, réglementation des contrats, exécution des contrats, régles de défaut interprétation.

Key words : Contract theory, Contract regulation, Contract enforcement, Default rules, Interpretation.

\section{I. - INTRODUCTION}

Discussions of regulation commonly focus on regulating particular industries, such as the airline industry, or regulating types of firms, such as natural monopolies. These discussions often concern the substance of the transactions that regulated firms make. Few regulatory discussions focus on regulating contracts as such. As an example of the distinction just drawn, a regulation discussion may ask what terms a regulated firm can include in its contracts with customers; a discussion of contract regulation may ask what terms the state should supply to firms to use in transactions with each other. In recent years, law and economics scholars have begun to add to the question which contract rule would be appropriate in particular cases the more abstract question regarding how the state should regulate contracts between business firms as a general matter. Contract regulation as a distinct area for scholarly inquiry is in its infancy, however (1). This essay's goal is to introduce the subject and to indicate its importance in the hope that more detailed treatments will follow (2).

(1) Early treatments of the topic are in Schwartz (1992a) and Tirole (1992). Citations to more recent work will appear below.

(2) Courts will not enforce contracts that create externalities, such as agreements to fix prices. There also is considerable regulation of contracts between firms and consumers, commonly rested on the ground of an imbalance in sophistication and resources between these parties. Contracts that create externalities and consumer contracts are beyond the scope of this essay. 
An economic theory of contract regulation will have a substantive and an institutional aspect (3). The substantive aspect asks what the state should do. The institutional aspect asks which legal institutions should perform the needed regulatory tasks. Given the complexity of the subject and the necessary brevity of this essay, any conclusions respecting these aspects must be tentatively held. With this disclaimer and beginning with substance, the state appears to do four things well : enforce contracts; police the contracting process for fraud and duress ; supply parties with common vocabularies to use when writing contracts ; and supply parties with governance modes for the conduct of transactions or the resolution of disputes. It should do only these things, and not the additional things that it sometimes attempts. An example of such an additional thing is the attempt to implement an ex post fair solution in a particular case when both contract and renegotiation have failed. Regarding the institutional aspect of the theory, only courts can perform the first two tasks just listed ; only legislatures can do the last ; and the third task commonly is and should be shared between the legislative and adjudicatory institutions (4).

\section{II. - THE SUBSTANTIVE FUNCTION}

Law and economics scholars have proposed five regulatory functions for inter-firm contracts.

(1.) Enforcing a contract's verifiable terms : Enforcement is specific when the state orders a party to perform the task or to make the transfer that the contract directs. Enforcement also can be by a damage sanction, as when the breaching party is required to pay to its contract partner the profit that the partner would have earned had the contract been performed.

(2.) Supplying vocabularies : The state cannot enforce a contract unless it knows what the contract says. A way to know this is to supply parties with a stock of common meanings, and this is done in three ways. First, the state can

(3) A competing theory of contract regulation that is pursued largely by legal scholars holds that the state should enact contract rules that are fair and that promote community among contracting parties. An extensive treatment of this theory is in Collins (1999). Implementing a fairness theory is difficult when parties have the freedom to alter fair legal rules that do not maximize their expected gains. This point is developed in a little more depth in Part 3B below.

(4) Private associations often create rules to regulate transactions among the members and between members and outside parties. These rules have the legal status of contracts made among an association's membership. The question whether courts should treat these contracts as they do ordinary market contracts is unsettled in the law and among commentators, but there is a tendency for courts to enforce the contracts as written when the rules are clear. An interesting study of the contrast between the adjudicatory practices of courts and the adjudicatory practices of the institutions that private associations create is Bernstein (1996). 
restrict parties to the dictionary meanings of the words they use, unless a contract at issue explicitly defines a commonly used word in an idiosyncratic manner. Second, a court when deciding cases or a statute can define commonly used words or phrases in the customary way. For example, the phrase « FOB Seller's place of business » has long meant that the buyer is to bear the expense and risk of transporting the goods once the seller delivers them to the carrier. Commercial statutes now define the FOB phrase in this way. As a consequence, if a contract uses the FOB phrase and the goods are damaged or destroyed while in transit, the seller is entitled to the price and the buyer bears the loss. Third, the state can adopt for purposes of adjudication the meanings that private trade associations have developed (5).

(3.) Interpreting agreements : The adjudicator asks what the parties to the contract before it meant by the words they used. It is the particular meaning that controls. If particular parties meant by the phrase «FOB Seller's place of business » that the buyer was to bear the expense of shipping the goods, but not the risk of their damage in transit, then on this interpretative theory if the goods were damaged, the seller could not recover the price unless it shipped new goods.

(4.) Supplying default rules : The three principal types of default rules are (6) :

A. «Problem solving » default rules: The state supplies parties with rules that maximize expected surplus. Awarding a party the gain it would have made under the contract had the other party performed is efficient with respect to the decision whether to breach the contract or to perform it. Hence, a legal rule that awards the gain if the contract is silent maximizes expected surplus, at least with respect to the breach decision.

B. Information forcing default rules : The state supplies rules that seldom would be optimal for the party with private information. The effort of this party to contract out, it is hoped, will reveal information that is needed for efficient trade or investment. For example, suppose that one party can increase the probability of a successful performance by increasing the amount of effort it commits. This party could not choose the optimal effort level if it is uninformed as to the value that a successful performance would have. In this circumstance, a legal rule that would award the passive but informed party no remedy if performance turned out to be unsuccessful may induce this party to disclose its valuation, thereby facilitating the taking of efficient precautions by the uninformed performing party. See Bebchuk and Shavell (1999).

(5) There are fewer such generally accepted, privately created meanings than had been supposed. See Bernstein (1999).

(6) A complete taxonomy of default rule types is found in Schwartz (1994). 
C. Fair default rules: The state supplies parties with rules that are fair according to some normative conception. To illustrate, courts and commentators often think that it is fair for the seller to supply conforming goods when the buyer has paid a nontrivial price. The law generally implies a warranty - the seller must compensate the buyer if the goods are defective - and this is sometimes said to follow from the law's commitment to fairness.

(5.) Regulating the contracting process : This function has several aspects :

A. Not enforcing contracts that were procured by fraud, such as misrepresenting the quality of a performance that is to be rendered.

B. Not enforcing modifications to contracts that were procured by exploiting sunk cost investment.

C. Implementing the ex post efficient solution. As an example, when circumstances have materially changed between the time the contract was made and is to be performed, such that enforcement would benefit one of the parties but make society worse off on net, commentators urge courts not to enforce, and some courts heed this advice.

D. Implementing the ex post fair solution. Continuing with the example, if performance would give one party a windfall gain, commentators urge courts to reduce the gain to a fair level, and courts occasionally attempt to do this.

\section{III. - THE INSTITUTIONAL ASPECT OF CONTRACT REGULATION}

\section{A. What is possible?}

In common law countries, courts today perform all five regulatory functions. The contract parts of Civil Law Codes tend to be written on a fairly high level of abstraction because the Codes regulate many different transaction types. This confers considerable discretion on courts, and it would be interesting to test the hypothesis that courts in Civil Law countries also perform these five functions. In any event, legislatures cannot perform functions (1.) - enforcement - (3.) - interpreting agreements - and much of (5.) - regulating the contracting process - because these are adjudicatory functions. To enforce a contract (function (1.)) or to find what particular parties meant by the words they used (function (3.)) require case by case inquiries. Legislatures supply rules. Function (2.), the supplying of contracting vocabularies, is shared between courts and legislatures. A statute cannot define every word or phrase that parties into the indefinite future may use in the contracts they will write. Courts on the other hand must give legal effect to the words in a contract ; and the definitions they develop in the course of doing this often are held to specify the legally operative meanings when the same words appear in later contracts. Hence, courts necessarily play a residual role in supplying contrac- 
ting vocabularies, even when the legislature has enacted a vocabulary itself (7). The policing function (function (5.)) also can be shared. For example, the legislature can direct courts to ignore windfalls when deciding cases or it can create standards by which courts must assess whether fraud has been committed. Legislatures seldom seem to perform these tasks, so the policing function (5.) is today performed exclusively by courts.

This is not to say that courts can perform every aspect of this function well. Thus, a court seldom would have the information to implement the ex post efficient solution (function $5(\mathrm{C})$ ). This is because courts receive information only from the parties. If parties are symmetrically informed ex post, however, they will bargain to the efficient solution, so that courts will not see the case. If courts see only cases in which information is asymmetric, then they will lack the information to implement the efficient solution. As an illustration, let it be efficient to breach a particular contract because the seller's cost to perform would exceed the buyer's valuation, but suppose that the seller's cost is neither observable nor verifiable. The parties, suppose, cannot agree on a price for breach, the seller refuses to perform and the buyer sues. The court cannot know whether breach would be efficient or not ; and since the seller's refusal to perform is itself verifiable, the court can only enforce the contract (8).

A court also could not perform function 5(D), implementing the ex post fair solution, because courts act subject to the institutional constraint that they decide according either to pre-existing legal or moral principles. Any division of ex post gains between two business firms would be arbitrary; that is, there is no legal or distributional principle that would permit a court to decide whether it is fair to give the plaintiff or the defendant particular shares. Since legislatures cannot perform functions $5(C)$ and (D) - implementing ex post efficient or fair solutions - these functions should not be performed for institutional reasons ; that is, the limited competencies of legal institutions imply that the state should not alter the performances that contracts require to achieve either ex post efficiency or ex post fairness.

Before asking which of the remaining regulatory functions should be performed and by whom, it is worth noting that the two interpretative functions

(7) As an illustration, the American Uniform Commercial Code creates a set of default rules to regulate sales transactions. These rules use terms that are derived from commercial practice, but the Code defines them explicitly. Hence, parties who today use a statutorily defined term are held to intend the statutory meaning. The original Code's list of terms is not exhaustive, however, so courts are continually defining new terms, some of which have been incorporated into Code revisions. This process continues.

(8) In addition to this theoretical difficulty, parties seldom would want a court to implement an ex post efficient solution in the rare cases when it could because commercial agents need prompt answers. Litigations take a long time, so that any otherwise efficient solution usually would be outmoded before it could be devised. Perhaps for the reasons given in text and in this note, courts seldom attempt to implement ex post efficient outcomes. There are examples of these attempts in connection with long term contracts. 
sometimes will be inconsistent. Parties will be less inclined to use judicially or statutorily defined phrases if courts will permit a party who turns out to suffer from a rigid application of a definition to introduce evidence that in precontract conversations the parties indicated that a rigid application was not their intention. Rather, parties will more frequently themselves define the words they use in the contracts they write, an effort that is more costly but more predictable than relying on preexisting but malleable definitions. On the other hand, a rigid application of pre-existing definitions may impose obligations that some parties did not intend to assume. Thus, there is a tension between the "vocabulary supplying » (2.) and the " meaning finding » (3.) contract interpretation functions. See Scott (2000).

\section{B. What is desirable?}

The virtues of contract enforcement need not be stressed but there is a point to be made about enforcement modes. A contract can be « enforced » by awarding damages to the injured party or by specifically enforcing the actions that the contract requires. Solutions to the problem of inducing efficient relation specific investment commonly involve the use of contracts that condition on verifiable subsets of information, and that require specific enforcement of the transfers that the contracts direct (9). A practical objection to these solutions is that contract enforcement takes time, but subject to this difficulty European laws that make specific performance relatively easy to get are preferable to common law rules that make it difficult. Also, the desirability of preventing fraud and exploitation (functions 5(A) and (B)) is obvious.

Turning to functions (2.) and (3.), the vocabulary supplying function is noncontroversial when it is stated in isolation, but becomes controversial when the tension between it and the interpreting agreements function of (3.) is made explicit. This is because the two functions partly derive from distinct normative goals. The vocabulary supplying function is efficient. Providing a contractual vocabulary is a public good. When parties have a common vocabulary, they can know what they are agreeing to and what will be enforced. The costs of supplying standardized contract terms will often exceed the gains for particular contracting parties. Also, a party who would be disappointed in the deal if it were enforced has an incentive to cheat ex post, by claiming that the parties made a different deal - that they intended the words they used to have a meaning particular to them. In sum, private parties will create suboptimal sets of vocabularies, and a common contractual vocabulary could not survive unless it was made mandatory by judicial enforcement of the statutory or case created meanings.

The meaning finding function of interpretation follows from autonomy norms. Under these norms, a person cannot be made to take, or to be preven-

For a review, see Schwartz (1998). 
ted from taking, lawful actions without his informed, voluntary consent. Hence, when a contract is sought to be enforced against a person, that person must be permitted to offer evidence as to the actual meaning that the parties intended the contract's words to have. Evidence relevant to this question can be found in what was said and done before the contract was made, from the customs of the industry or trade in which the parties exist, and from any conduct ex post that can shed light on what the written words meant to the people who actually used them. When a court permits such evidence to be introduced, it is said to engage in contextual interpretation, and when a court refuses to consider such evidence in favor of applying standard meanings in standard ways, it is said to engage in acontextual interpretation. Courts in the United States vacillate between these two modes of interpretation, but it is difficult to discern a principle underlying the decisions (10).

Resolving the conflict between the vocabulary supplying function (2.) and the interpreting agreements function (3.) is beyond the scope of a short essay such as this, but a remark is in order. Autonomy norms are strongest when a contract is sought to be enforced against an individual, and lose force as the defendants become companies. Hence, a normative theory of contract regulation whose subject is transactions among firms should prefer courts to abandon function (3.) in favor of function (2.). A less definitive solution is to let adjudicatory methods be default rules, so that courts which are using acontextual interpretation would switch to a more literal enforcement mode when the parties' contract so requested (11). It is unclear how this suggestion would work in practice.

Function 3(C) - supplying fair default rules - arguably should not be performed by any state institution. This is because the set of surplus maximizing rules and the set of fair rules, by any normative criterion, likely are disjoint. Business parties will contract out of «fair but inefficient » default rules. As a consequence, while a decision maker may want to resolve choices among legal rules by fairness norms when all of the feasible rules are on the pareto frontier, the supplying of fair default rules independently of their efficiency can be wasted effort for the rule creators and will impose unnecessary contracting costs on parties.

The remaining functions to consider are 5(B) and (C), supplying parties with problem solving and information forcing default rules. The problem solving task can be divided into two subfunctions : (a) Providing modes of governance, such as a corporate form or a bankruptcy scheme ; (b) Solving particular problems, such as the scope of the seller's obligation to supply product quality. The rationale for providing both functions is the same : supplying a governance mode or a solution to a complex but commonly recurring problem will often cost particular

(10) For a discussion, see Posner (1998).

(11) This is suggested in Bernstein (1996). 
parties more than the gains that the mode or form could yield to them. A court could not supply a governance mode because courts exist to decide disputes, not create business regulating codes. In addition, parties to a litigation will supply courts with information that may help to win a case, but will not supply information necessary to create an entire governance mode. Courts sometimes can supply rules to solve more particular problems. Thus, courts never but legislatures can and sometimes do supply parties with default governance modes, and both institutions sometimes attempt to solve particular problems.

The public goods aspect of supplying solutions to problems implies that problem solving default rules should be created, but there is a distinction between supplying governance modes or dispute resolution schemes and the solving of particular problems. The former sets of solutions can be highly general, and applicable to a wide range of commercial behaviors. Thus, many different types of business activity can be conducted in the corporate form. In contrast, attempting to solve particular problems will often founder on the heterogeneity of large, modern economies. The state creates rules either through adjudication, which is expensive and time consuming, or by legislation, which also is costly and takes time. Consequently, state solutions to problems will not be cost justified unless the problems can be approached in a general way. Though commercial problems often are general - how to induce efficient sunk cost investment, for example - the solutions to these problems usually are specific. Contracts that may induce efficient investment thus condition on verifiable sets of information related to the costs and valuations of the parties to these contracts, and require transfers that are efficacious only in connection with these particular costs and valuations. See, e.g., Maskin and Tirole (1999) ; Edlin and Reichelstein (1996); Hermalin and Katz (1993). Hence, a set of state supplied default rules that attempted to induce efficient investment likely would approach in size the set of private contracts. This would not reduce social costs.

The disjunction between the need for state supplied default rules to be general in form and the need for particularist solutions to commercial problems has led to dramatic legislative failures. As an example, the Uniform Commercial Code provides that, when the contract is silent, sellers assume all risks associated with product quality, as a consequence of which the sellers must pay compensation for any loss a buyer suffers from a noncompliant product. Sellers of products that may cause substantial losses, especially when the products are complex, always contract out of this default rule. The sellers then specify the precise quality obligation and damage risk they are willing to assume, and these specifications differ across products. Thus, the Code warranty sections impose contracting costs that are large in the aggregate but create no offsetting benefits. This story can be retold for other rules, and its lesson is that there are few commercial problems whose solutions are sufficiently general to justify the supply of problem solving default rules by the state.

To the difficulty of heterogeneity must be added the related difficulty of asymmetric information. Parties will contract out of default rules that condi- 
tion on unverifiable information because such rules would produce moral hazard. The pervasiveness of the verifiability problem thus seriously constrains the regulatory function of supplying default rules to commercial parties. And in sum, the related difficulties of heterogeneity and asymmetric information suggest that legislatures seldom should attempt to create contract law rules that have the purpose of maximizing surplus for parties who accept those rules (12). These two difficulties do not plague to the same degree the function of creating default modes of economic organization, such as the standard partnership or business corporation.

The function of supplying information forcing default rules (4(C)) also suffers from the difficulties of heterogeneity and asymmetric information. The goal here is to supply rules that will induce separating equilibria, but it will be difficult for courts or legislatures to obtain the knowledge needed for inducing separation when the economic actors function in highly heterogenous economies, and there is considerable private information. See Adler (1999). Analyses of third degree price discrimination also suggest that separating agents is a context specific task. While the issue is still under debate, one conclusion is clear : writing useful problem solving or information forcing default rules is a harder task than was originally thought.

\section{IV. - CONCLUSION}

Jean Tirole has written : « The challenge for the economist is to develop a theory of the optimal judiciary scope of intervention (the class of problems over which the courts have discretion) and instruments (the menu of choices they face) ». The need actually is broader than this - to develop a theory of what the state in general should do regarding contracts and then to specify which legal institutions should perform which substantively desirable functions. This essay has sketched the possible functions the state can perform and made a few preliminary remarks about which of these functions are possible and desirable to perform. Courts can and should enforce the verifiable terms of contracts, police the contracting process to deter fraud and duress, and help to supply firms with a common vocabulary to use when making contracts. Legislatures should also supply vocabularies and create default modes of economic organization. At this early stage in our understanding of these issues, these are the most defensible tasks and institutional roles that it is possible to do and to play.

(12) Courts recognize these difficulties implicitly, and tend in asymmetric information environments to enforce only those terms that condition on verifiable information; they do not try to create new rules. See Schwartz (1992b). 
Many additional topics remain to be explored. These include whether parties should be permitted to choose the interpretative practices that courts will apply to their agreements ; whether courts should emulate the contracting practices of private associations; whether contextual interpretation helps parties to solve their own problems or hinders parties ; and the appropriate level of generality that legal default rules should take. Contract theory regulation thus has an interesting research program.

\section{REFERENCES}

ADLER, BARRY E. «The Questionable Assent of Hadley v. Baxendale », 51 Stanford Law Review 1547-89 (1999).

BEBCHUK, Lucian AYRE and Steven SHAVELL. « Reconsidering Contractual Liability and the Incentive to Reveal Information », 51 Stanford Law Review 1615 (1999).

BERNSTEIN, Lisa. "The Questionable Basis of Article 2's Incorporation Strategy : A Preliminary Study ", University of Chicago Law School Law and Economics Working Paper (2nd Series) No. 74 (1999).

, "Merchant Law In a Merchant Court : Rethinking the Code's Search for Immanent Business Norms », 144 Pennsylvania Law Review 1766-1821 (1996).

COLLINS, Hugh, « Regulating Contracts » (Oxford University Press, London 1999).

EDLIN, AARON S. and Stefan REICHELSTEIN. «Holdups, Standard Breach Remedies, and Optimal Investment », 86 American Economic Review 478-99 (1996).

HERMALIN, Benjamin A. and Michael I. KATZ, « Judicial Modification of Contracts Between Sophisticated Parties : A More Complete View of Incomplete Contracts and Their Breach », 9 J. Law, Econ. \& Org. 230-55 (1993).

MASKIN, Eric and Jean TIROLE, «Unforseen Contingencies and Incomplete Contracts », 66 Review of Economic Studies 83-114(1999).

POSNER, Eric A., "The Parol Evidence Rule, The Plain Meaning Rule, and the Principles of Contractual Interpretation », 146 Pennsylvania L. Review 533-77 (1998).

SCHWARTZ, Alan, "Incomplete Contracts » in The New Palgrave Dictionary of Economics and the Law 277-83 (Peter Newman, ed. 1998).

"The Default Rule Paradigm and the Limits of Contract Law », 3 Southern California Interdisciplinary Law Review 389-419 (1994). , "Legal Contract Theories and Incomplete Contracts 》 in Contract Economics 76-108 (Lars Werin and Hans Wijkander, eds. 1992a).

, "Relational Contracts in the Courts : An Analysis of Incomplete Contracts and Judicial Strategies », 21 J. Legal Studies 271-318 (1992b).

SCOTT, Robert E., "The Uniformity Norm in Commercial Law : A Comparative Analysis of Common Law and Code Methodologies » forthcoming in The Jurisprudential Foundations of Corporate and Commercial Law (Cambridge University Press, 2000).

TIROLE, Jean, «Comments », in Contract Economics 109-13 (Lars Werin and Hans Wijkander, eds. 1992). 